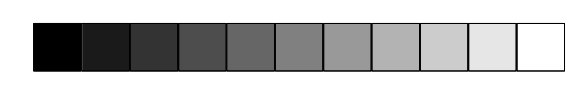

GEOUSP - Espaço e Tempo, São Paulo, No 18, pp. 197 - 198 , 2005

\title{
IX SIMPÓSIO NACIONAL DE GEOGRAFIA URBANA: CIDADES: TERRITORIALIDADES, SUSTENTABILIDADES E DEMANDAS SOCIAIS, MANAUS-AM, 18-21 DE OUTUBRO DE 2005
}

\author{
Anselmo Alfredo*
}

Manaus recebeu a Geografia de braços abertos e mostrou a importância de uma recepção atenta e organizada. A comissão organizadora esteve presente em cada detalhe, o que nos facilitou não só uma presença constante junto às atividades do encontro, mas uma convivência junto aos participantes que contribuíram em muito para com o debate.

o Simpurb, ao longo de suas nove edições, tem-se demonstrado como um fórum onde a Geografia Urbana brasileira se expressa tanto como produção científica, mas também enquanto tendências distintas e, mesmo, opostas.

A variedade dos temas mostra essa diversidade no pensamento sobre a questão urbana que, ultimamente, tem estabelecido diálogos com a Geografia internacional. Sustentabilidade e o urbano, a geografia das redes, a reprodução crítica da urbanização brasileira, a perspectiva contraditória entre concebido, vivido e percebido a compor o urbano como Cotidiano, a perspectiva genético-histórica da urbanização brasileira, as questões relativas à centralidade urbana, à produção do espaço enquanto espaço capitalista, são algumas dentre as diversas abordagens que compuseram o IX Simpurb em Manaus. Isto desde as mesas redondas até os painéis com pesquisas em andamento.

A presença deste fórum de debate em Manaus, contudo, não só se explica pela importância que o mesmo tem no fortalecimento das instituições que o recebem, dada a dimensão nacional e internacional do mesmo, mas revela também a presença de um pensamento geográfico em áreas onde a modernização se efetiva como fronteira, área de integração à forma-valor.

Manaus e suas áreas adjacentes comportam um processo de urbanização onde a forma pela qual a reprodução crítica de uma sociedade de consumo, ao que pese a Zona Franca de Manaus, se dá pela presença determinante da forma mercadoria sem, contudo, estabelecerem-se a efetividade de seus pressupostos produtivos.

Como resultado fenomênico tem-se a força impositiva do mundo da mercadoria a se reproduzir no interior de uma precariedade social que, contraditoriamente, integra esta reprodução. Isto é, o consumo e o mundo da mercadoria reproduzem-se apesar de seus pressupostos, apropriam-se, contraditoriamente, desta ausência, o que potencializa a compreensão da constituição social - a formação capitalista - como crítica e contraditória.

Não por acaso, para voltarmos ao Encontro, a presença da sustentabilidade e dos debates sobre o desenvolvimento regional, no âmbito nacional, contrapostos a uma abordagem crítica da reprodução das relações 
sociais de produção, ganharam uma importância particular em Manaus.

Estávamos diante de uma debate em que a expansão do mundo da mercadoria em áreas, portanto, de fronteira, coloca-se como uma expressão crítica da reprodução social, com suas mazelas sociais imanentes, mas que potencializou a dimensão de uma Geografia estatal intervencionista. Embora tratem-se de temas nacionais e internacionais expostos ao longo do Simpurb, Manaus deu este tom contextual ao Simpósio como um todo.

Em outras palavras, a reprodução crítica da sociedade capitalista, seja no seu plano formal e lógico, seja em sua constituição crítica histórica, revelou que a Geografia Urbana brasileira encontra-se diante de um debate dos mais importantes no contexto das ciências humanas. Ou seja, a necessidade de se compreender os limites da reprodução social assentada na reprodução ampliada da riqueza abstrata como algo auto-referente demanda tanto uma compreensão teórica fundamental para que se analisem tais limites, mas, ao mesmo tempo, constitui a possibilidade de fazer com que a ciência participe, através de uma perspectiva intervencionista que remonta à Geografia Ativa, como um do elos desta reprodução crítica. A expansão desigual da forma valor repõe, portanto, a atualidade tanto de um pensamento vinculado aos nexos da realidade posta como a necessidade de sua crítica. A Manaus devemos o mérito não só deste fértil, mas necessário debate.

A sustentabilidade, portanto, conjuntamente com o que se constitui como demandas sociais compôs, ao longo da semana, uma dimensão onde o debate estabeleceu a necessidade de se explicitar o próprio sentido contraditório da realização do capitalismo enquanto que um modo de produção cabal, isto é, com um sentido temporal que, em sua autoreferência, realiza-se plenamente, ainda que no interior de suas contradições. Estabeleceu-se, portanto, uma tensão (debate) sobre o sentido daquilo que se expressa como demandas sociais. Seriam elas a necessidade de uma intervenção estatal-científica que reponha os pressupostos do mundo da mercadoria como forma de socialização daquilo que é considerado como conquista social ou seriam elas (as demandas) uma revelação de que há que se construir uma crítica à modernização e ao civilizatório visto que as mesmas são integrantes e integradas à reprodução do mundo da mercadoria? Gestão ou auto-gestão?

Estas, dentre outras questões, foram fortalecidas pelos trabalhos de campo no último dia do encontro. As incursões na periferia de Manaus, o encontro das águas, as cidades ao longo dos rios Solimões e Rio Negro (Manacapuru e Novo Airão) dentre outros, estabeleceram a possibilidade de se nos confrontarmos com esta urbanização de fronteira e refletirmos sobre a modernização e o civilizatório como representação (na expressão de Lefebvre) ou fetiche (na expressão de Marx) da forma-valor que se quer universal.

Enfim, Manaus e o Simpurb mantêm vivos tanto a necessidade do debate como o reconhecimento da importância da Geografia e da Geografia Urbana na reflexão do mundo presente por seus diversos caminhos... 